\title{
Cover to cover
}

Anthony Troon writes from The Scotsman in Edinburgh: 'Another very readable issue. I like the new format.' Dr Alan Swan writes from the Ecole Centrale, Paris: 'I very much enjoy reading the magazine (and doing the crossword). Thank you for many hours of enjoyable reading.' Brian Howes writes from London (sending in some cartoons): 'The magazine keeps up a high level of interest. I read it from cover to cover on the first day it arrives.'

It is good to know, on ET's fourth anniversary, that numbers of readers like Brian Howes read from cover to cover. In the late $1980 \mathrm{~s}$, with so much media competition, this is a greatly appreciated response - and compliment. It is also good to know that the change of format has been a success, not only visually and in terms of physical durability, but also in economic terms. As we have mentioned before, ET has no safety net of sponsors or subsidies.

We are sorry, however, after so much publicity, when people still write in saying they have only just heard of it or seen their first copy - or ask, like Dr William Mittins of the University of Newcastle-on-Tyne in England, how it can be that of a whole group of English teachers (in the UK on a British Council course) not one had heard of English Today. It may well take another four years to put that kind of problem right. But word of mouth does help.

Separately, several readers have asked for (1) an ET index, and (2) regular examples of excellent writing in English. We have given both matters serious thought and currently conclude that the complexities of indexing would eat ferociously into the time we can give to producing the quarterly issues (None of us work/works full time on $E T$ ). On the matter of good prose, despite ingenious suggestions from various readers, we incline towards the position of Boman Desai (author of the 1988 novel Memory of Elephants) writing from Chicago:

'The New York Times Book Review chooses five examples of "well-written English" each week for its "Noted with Pleasure" column, but I would disagree with at least two of the examples each week. I think it's one of those tasks that one undertakes at one's peril.'

But we'll keep an open mind on all such matters and look forward to hearing from a good cross section of readers in 1989.

Tom McArthur

The editorial policy of English Today is to provide a focus or forum for all sorts of news and opinion from around the world. The points of view of individual writers are as a consequence their own, and do not reflect the opinion of the editorial board. In addition, wherever feasible, ET leaves unchanged the orthography (normally British or American) and the usage of individual contributors, although the editorial style of the magazine itself is that of Cambridge University Press.

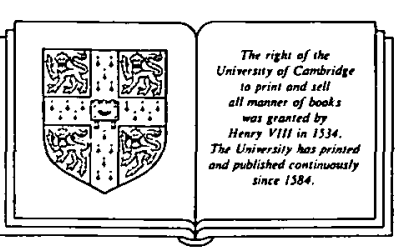

(C) Cambridge University Press 1989. No contents may be reproduced by any means without the permission of Cambridge University Press.

English Today (ISSN 0266-0784) is a quarterly. ISBN 0521378443

UNITED KINGDOM:

Publisher: Cambridge University Press, Edinburgh Building, Shaftesbury Road, Cambridge CB2 2RU. Telephone (0223) 312393

Subscriptions: the current annual subscription price for four issues for libraries and institutions is $\mathrm{E} 32$ in UK, £35 elsewhere; $₹ 16$ for individuals;

$\Sigma 12$ for students and the retired airmail £8 per year extra. Apply to Paul Driver.

Promotion: write to Sarah Nichols, at the above address.

Advertising Sales: write to Andrew Patterson at Rooms 484-6,

Tavistock House South, Tavistock

Square, London WC1 H 9JZ.

Telephone (01) 388 7487/8/9.

USA AND CANADA:

Publisher: Cambridge University Press, 32 East 57 th Street, New York 10022. Telephone (212) 6888888.

Subscriptions: the current annual subscription price in USA and Canada for libraries and institutions is $\$ 54$; $\$ 27$ for individuals; $\$ 20$ for students and the retired; Copies are air-freighted to New York to arrive with a minimum delay. Apply to Hamy Florentine.

Promotion: write to Harry Florentine at the above address.

Advertising Sales: write to Stefanie Weiss at the above address.

Application to mail at second class postage rates pending at New York, NY and at additional mailing offices. POSTMASTER: send address changes in USA and Canada to English Today, Cambridge

University Press, 510 North Avenue, New Rochelle, NY 10801

Letters to the Editor: write to Dr Tom McArthur, Editor, English Today, 22-23 Ventress Farm Court, Cherry Hinton Road,

Cambridge CB1 4HD, UK.

Typeset by Goodfellow \& Egan. Printed in Great Britain at the University Press, Cambridge. 